\title{
Concurrent Field Practice Act as an Efficient Teaching Pedagogy to Originate Public Health Professionals: A Bangladesh Context
}

\author{
Bilkis Banu ${ }^{1,2,}$, Sayed Asaduzzaman ${ }^{3}$, Nas rin Akter ${ }^{2}$, Sarder Mahmud Hossain², Touhid Bhuiyan ${ }^{3}$ \\ ${ }^{1}$ Heidelberg Institute of Global Health, Heidelberg University, Germany \\ ${ }^{2}$ Department of Public Health, Northern University Bangladesh, Dhaka, Bangladesh \\ ${ }^{3}$ Department of Software Engineering, Daffodil International University, Dhaka, Bangladesh
}

Received January 20, 2020; Revised April 18, 2020; Accepted May 3, 2020

Copyright $\odot 2020$ by authors, all rights reserved. Authors agree that this article remains permanently open access under the terms of the Creative Commons Attribution License 4.0 International License

\begin{abstract}
Concurrent Field Practice-based teaching methods (CFPTM) have commenced globally parallel with the traditional teaching methods (TTM). The effectiveness of CFPTM in Bangladeshi educational settings has not been adequately studied yet. This study was undertaken to test the hypothesis that CFPTM is effective teaching method as compared to the TTM for Bangladeshi postgraduate public health students. Under a comparative interventional design two groups of postgraduate students [ $n=40$ for each group], were selected purposively fro $m$ the department of public health of the Daffodil International University, Dhaka, Bangladesh. Data were collected during pre and post intervention based on a topic that had been chosen to conduct the intervention followed interactive lecture method with CFP. Overall knowledge score (percentage) showed a significant increase in both the CFPTM (Baseline vs. Final, $\mathrm{M} \pm \mathrm{SD}, 27 \pm 12$ vs. $83 \pm 8$, $\mathrm{p}<0.001)$ and TTM $(27 \pm 18$ vs. $40 \pm 17, \mathrm{p}<0.001)$ a mong the groups. CFPTM showed a significantly higher knowledge score $(\mathrm{p}<0.001)$ as compared to TTM at the final time point. Analysis on individual components showed a result similar to the overall knowledge score. CFPTM seems to be superior and effective to TTM as a short-term interventional tool. CFPTM has been identified as an effective tool for postgraduate education in public health, which offers a new approach to equipping students with appropriate knowledge and skills that they need not only in their learning period but also in their service life.
\end{abstract}

Keywords Concurrent Field Practice, Teaching method, Public health, Bangladeshi Context, Knowledge Score

\section{Introduction}

Educating the professional in social and health care has been a common practice nowadays but simultaneously has become challenging by the global circumstances. Numerous factors such as socio-economic conditions, difficult political environments as well as lack of awareness, have influenced the ability to provide training for these health care professionals, according to Shardlow [1]. For the social work practitioners as well as public health professionals, field education is a pivotal feature for enrich ment of their skill and professionalis m. Many of the Universities achieved competence in social work through field education and got it fully accessible for faculties and prospective students [2].

In 2003, Institute of Medicine (IOM) Reports, Whom Will Keep the Public Healthy? Educating Public Health Professionals for the 21st Century made it clear that academic public health programs should have a primary mission that is the preparation of individuals for positions of senior responsibility in public health practice, research, and teaching [3]. Public health programs need to ensure that their curriculums are structured to meet the contemporary needs of the practice in community. Thus, as there are needs to change the community, so, the curriculum of the public health programs needs to adjust accordingly.

Innovative and effective in curricular modification and effectiveness in profession is going to meet the needs of educating the next generation of public health leaders. As creative and new ideas are explored, such as "schools without walls", people must address the challenges posed by providing cohesive degrees to students with whom they rarely? interact other than via computer, text messaging, and cell phone [4]. Teacher's education and student's 
participation in concerned field placements are more beneficial and create an opportunistic environment for learning. In this noble approach teachers become prospective and help the students for instrumental understanding that influence multiple sources of informative learning [5]. An innovative research found field based science teaching method increases the general and personal science teaching efficacy of the pre-service teachers at a public elementary school[6].

In professional arena other than Public Health for instance accounting discipline, emphasis on using innovative teaching practices such as information and communication technologies, the internet as well as various computer programs, simulations, case studies on real and virtual work environments, help graduates meet and adopt to the demands for professional competency development [7].

Can blogs, vlogs and wikis be substitute for lectures and classroom discussions? Can schools that have no residential faculty provide public health degrees? These and other questions challenge faculty and administrators as providing education to more students are undertaken and bolstered the public health workforce. All one has to do is to look at the Council for Education on Public Health (CEPH)'s website to see that dozens of accredited programs and schools of public health now rely on alternative strategies (online, executive-style, distance education) [4] to prepare public health practitioners. Yet there is still resistance to provide training via this mode, and for many universities outside the United States, online education is still viewed with skepticis $m$ and is limited in its offerings from Council for Education on Public Health [8].

The public health workforce has changed dramatically due to rapid social, technological, political and economic changes $[9,10]$ but public health education system has proceeded in general pattern and has not followed the approach of professions that consign internship or practical experience to the last phase of education. Instead, public health educators were not advanced among the early defenders and definers of experiential education and they saw fieldwork as a concurrent adjunct to classroom instruction; a sort of laboratory for the curriculum [10]. Presently, departments of Public Health have become more responsible for the provision of basic knowledge to make effective the learning, and are more active in helping students to connect their field experiences with classroom learning through introducing group work which encourages peer learning and peer support [11, 12].

Whereas group work, under proper conditions, has been shown to encouraged peer learning and peer support [13], group work can also become the vehicle for acrimony, conflict and freeloading. It may also impose a host of unexpected stresses on, for example, students with overcrowded schedules living long distances from the University [14].
Concurrent field practice (CFP) is a process by which postgraduate students can adopt theoretical knowledge appropriately by performing simultaneously different activities at the field level [15]. It reflects community-based research and problem-based learning. The objective of the CFP is to prepare professionals who will function at the interface of both fields in practice, research, planning, ad minis tration, and policy development in public health field. Students will develop competence in social work practice in community health, understanding of the organization and functioning of the health and social service delivery systems, and basic analytical skills necessary to conduct research and to perform competently in a variety of public health social work roles. Students will also have an opportunity for in-depth study of particular issues related to their special interests and career goals. CFP is a commonly included technique in postgraduate curricula in social sciences, but it is rarely practiced in public health disciplines [15].

Traditional teaching method (TTM) is usual practice in educational institutes. In recent years, concurrent field practice based teaching method (CFPTM) has gained a substantial implementation and is now as common as TTM [16]. A meta-analysis proved that non-traditional or evidence based teaching and learning methods designed to improve critical thinking which is more applicable for Public Health and Clinical practice are significantly more effective than the conventional methods [17].

It is very essential to as sess the effectivenes s of CFPTM compared to TTM before recommend the method for adopting in the public health curriculum. But the effectiveness of CFPTM in Bangladeshi educational settings has not yet been adequately studied. This study was undertaken to test the hypothes is that CFPTM is effective teaching method as compared to the TTM for Bangladeshi postgraduate public health students.

\section{Materials and Methods}

The effectiveness of CFPTM was measured by comparing the change in knowledge of CFPTM group with TTM group. An interventional study was conducted over a period of six months during September 2017- February 2018. Subjects were public health students at the Daffodil International University (DIU) in Bangladesh. DIU is one of the leading private universities of Bangladesh and established in 2002. The department of Public Health of DIU started its journey since 2012_with a great emphas is on both teaching and research. Initially all students of the Fall Semester in Master of Public Health Program (MPH) conducted by the department of Public Health, DIU were enrolled as the sample. A total of 96 students were the Semester and approximately 10 students were excluded from the study due to illness or absence. Considering insufficient number of students in the sample, a purposive 
selection into groups was made basing on the willingness of the subject to participate in the study. 03 students from each group were barred to continue in this study up to the final point and a total number of 80 students were available for this study with 40 students in each group. The groups were separated on the basis of section and 40 students from each section were taken. The data in both demographics and knowledge of selected topic were collected in two phases (pre-and post-assessment) from all subjects via a self-administered method with semi-structured questionnaire. The questionnaire was in the English version to assess knowledge on different components (Problem and need identification, goal, and objective setting, educational content setting, target group setting, selection of appropriate methods and media, detail plan of action, techniques of evaluation) of the selected topic 'Planning, Implementation and Evaluation of Health Educational Intervention'. The demographics included age; sex; religion; academic background of education (level of education, basic and academic result of last degree) and professional information (types of current organization, frequency of attendance in training and conference and publication if any. Before data collection, permission had been taken from the concerned authority of the university. All concerned students were informed about the study.

After collection of pre-intervention data, educational intervention were conducted among these two groups. Both groups were provided instruction on the topic of planning, implementation and evaluation of health education programs. After the standard lecture, students in the intervention or Concurrent Field Practice Teaching Method (CFPTM) group participated in an interactive process with practical/ demonstration part. But students in the non-intervention or Traditional Teaching Method (TTM) group were kept with the traditional lecture method. There was no practical/ demonstration conducted for TTM group after the lecture. The educational intervention was followed interactive lecture method with CFP by using module and practical sheet over a period of 6 hours (2 hours theory and 4 hours practical) for the CFPTM group and educational intervention followed only interactive lecture method over a period of 6 hours theory for the TTM group.

After coding, an overall knowledge score and individual knowledge score were compiled. Each correct response of knowledge was assigned a score of 1, each incorrect response was assigned a score of 0 and for multiple answers, a score of 1 was divided by total number of answers which were present. Afterwards, total scores were converted to percentage. Statistical package for Social Sciences (SPSS) 20.0 was used to analyze the data. Data were presented by mean and standard deviation values and compared using Paired-t-test between baseline and final values in each group as well as by using Independent t-test between the two groups at each time points. p-value $\leq 0.05$ was considered as significant with $95 \%$ confidence interval.

\section{Findings}

The Mean $\pm(\mathrm{SD})$ of age (in years) was found to be similar $(34 \pm 6)$ in both CFPTM and TTM groups in this research. The $\mathrm{M}( \pm \mathrm{SD})$ of total knowledge score (expressed as a percentage) of pre-ass essment were $27( \pm 18)$ $\& 27( \pm 12)$ respectively in TTM and CFPTM groups. Total knowledge score showed significant $(\mathrm{p}<0.001)$ increase after educational intervention and the scores were $40( \pm 17)$ $\& 83( \pm 8)$ respectively in both TTM and CFPTM groups. The final scores of both groups, CFPTM group showed a significantly $(\mathrm{p}<0.001)$ higher knowledge score as compared to TTM group in post-assessment. (Table 1)

The M $( \pm \mathrm{SD})$ of pre-as sessment knowledge score of the planning component of the topic 'Planning, Implementation, and Evaluation of Health Educational Intervention' were $31( \pm 24) \& 36( \pm 22)$ respectively in TTM and CFPTM groups. Total knowledge score showed significant $(\mathrm{p}<0.001) \quad$ increase after educational intervention and the scores were $48( \pm 23) \& 93( \pm 10)$ respectively in both CFPTM and TTM groups. However, between the last scores of both groups, CFPTM group showed a significantly $(\mathrm{p}<0.001)$ higher knowledge score as compared to TTM group in post-assessment. (Table 2)

The M $( \pm \mathrm{SD})$ of pre-as sessment knowledge score of the implementation component of the topic found $2( \pm 15)$ $\& 12( \pm 33)$ respectively in TTM and CFPTM groups. Total knowledge score showed significant $(\mathrm{p}<0.001)$ increase after educational intervention and the scores were $5( \pm 22) \&$ $80( \pm 40)$ respectively in both TTM and CFPTM groups. However, between the last scores of both groups, CFPTM group showed a significantly $(\mathrm{p}<0.001)$ higher knowledge score as compared to TTM group in post-assessment. (Table 2)

The M $( \pm \mathrm{SD})$ of pre-as sessment knowledge score of the evaluation component of the topic revealed $42( \pm 50) \&$ $70( \pm 46)$ respectively in TTM and CFPTM groups. Total knowledge score showed significant $(\mathrm{p}<0.001)$ increase after educational intervention and the scores were 55( \pm 50$)$ $\& 100( \pm 0)$ respectively in both TTM and CFPTM groups. But, between the end scores of both groups, CFPTM group showed a significantly $(p<0.001)$ higher knowledge score as compared to TTM group in post-assessment. (Table 2)

Table 3 reveals that females dominated both groups (CFPTM 55\% and TTM 65\%) and total knowledge score found more among females than males of CFPTM group after the educational intervention. (Table 3).

The educational background of the study subjects showed, the majority completed undergraduate/ bachelor degree as their last degree, before they started their MPH course [CFPTM: $36(90 \%)$ and TTM: 22 (55\%)]. Their undergraduate background came from science [CFPTM: 38 (95\%) and TTM: $40(100 \%)]$; most were non-medical 
graduate [CFPTM: $25(62 \%)$ and TTM: $22(55 \%)$ ] and with good academic result [CFPTM: $21(52 \%)$ and TTM: $25(62 \%)]$ in both groups. Moreover, total knowledge score were found higher during post-assessment among the students of CFPTM group who had completed postgraduate/ masters as the last academic degree, from a science background and medical graduate (Table 4).

Table 5 shows that most of the students were from non-government or private organization [CFPTM: 25
(62\%) and TTM: $31(77 \%)$ ]; and with more attendance in different types of professional training related to public health [CFPTM: 24 (60\%) and TTM: 23 (57\%)]; few published articles [CFPTM: 02 (5\%) and TTM: $06(15 \%)]$ were done by either groups. Only around $30 \%$ of the CFPTM group had attended various types of professional conferences, with over $50 \%$ of the TTM group having attending a profes sional conference.

Table 1. Effect of educational intervention on total knowledge score

\begin{tabular}{|c|c|c|c|}
\hline \multirow{2}{*}{ Groups } & Pre-Assessment & Post-Assessment & \multirow{2}{*}{$\mathrm{t} / \mathrm{p}$} \\
\cline { 2 - 4 } & $\mathrm{M} \pm \mathrm{SD}$ & $\mathrm{M} \pm \mathrm{SD}$ & $12.33 / .001 *$ \\
\hline TTM $(\mathrm{n}=40)$ & $27 \pm 18$ & $40 \pm 17$ & $25.92 / .001 *$ \\
\hline CFPTM $(\mathrm{n}=40)$ & $27 \pm 12$ & $83 \pm 8$ & \\
\hline $\mathrm{t} / \mathrm{p}$ & $0.143 / .887$ & $14.300 / .001 *$ & \\
\hline
\end{tabular}

$\mathrm{n}=$ number of subjects; $\mathrm{M}=$ mean; $\mathrm{SD}=$ st andard deviation; $\mathrm{t}=\mathrm{t}$ abulated value; *=significant; $\mathrm{p}<0.005$ was taken as level of significance

Table 2: Effect of both type of Educational Intervention on Individual components of Knowledge Score (expressed as percentage)

\begin{tabular}{|c|c|c|c|}
\hline \multirow{2}{*}{ Groups } & Pre-Assessment & Post-Assessment & \multirow{2}{*}{$\mathrm{t} / \mathrm{p}$} \\
\hline & $\mathrm{M} \pm \mathrm{SD}$ & $\mathrm{M} \pm \mathrm{SD}$ & \\
\hline \multicolumn{4}{|l|}{ 2.1 Planning } \\
\hline TTM $(n=40)$ & $31 \pm 24$ & $48 \pm 23$ & $12.50 / .001 *$ \\
\hline CFPTM $(n=40)$ & $36 \pm 22$ & $93 \pm 10$ & $18.61 / .001 *$ \\
\hline$t / p$ & $1.017 / .312$ & $10.931 / .001 *$ & \\
\hline \multicolumn{4}{|c|}{ 2.2 Implementation } \\
\hline $\operatorname{TTM}(\mathrm{n}=40)$ & $2 \pm 15$ & $5 \pm 22$ & $1.00 / .323$ \\
\hline CFPTM $(\mathrm{n}=40)$ & $12 \pm 33$ & $80 \pm 40$ & $9.00 / .001 *$ \\
\hline$t / p$ & $1.708 / .092$ & $10.931 / .001 *$ & \\
\hline \multicolumn{4}{|l|}{ 2.3 Evaluation } \\
\hline $\operatorname{TTM}(\mathrm{n}=40)$ & $42 \pm 50$ & $55 \pm 50$ & $2.36 / .023$ \\
\hline CFPT M $(\mathrm{n}=40)$ & $70 \pm 46$ & $100 \pm 0$ & $4.088 / .001 *$ \\
\hline$t / p$ & $2.548 / .013$ & $5.649 / .001 *$ & \\
\hline
\end{tabular}

$\mathrm{n}=$ number of subject $; \mathrm{M}=$ mean; $\mathrm{SD}=$ st andard deviation; $\mathrm{t}=$ tabulated value; $*$ =significance; $\mathrm{p}<0.005$ wast aken as levelof significance, performed paired and independent $t$ test

Table 3. Effect of both types of Intervention on total knowledge score according to background characteristics (Personal Information) of study subjects

\begin{tabular}{|c|c|c|c|c|c|c|}
\hline \multirow{3}{*}{ Parameters } & \multicolumn{3}{|c|}{ TTM Group $(n=40)$} & \multicolumn{3}{|c|}{ CFPT M Group $(n=40)$} \\
\hline & \multirow{2}{*}{$\begin{array}{c}\mathrm{n} \\
(\%)\end{array}$} & Pre-intervention & Post-intervention & \multirow{2}{*}{$\begin{array}{c}\mathrm{n} \\
(\%)\end{array}$} & Pre-intervention & Post-intervention \\
\hline & & \multicolumn{2}{|c|}{$\mathrm{M} \pm \mathrm{SD}$} & & \multicolumn{2}{|c|}{$\mathrm{M} \pm \mathrm{SD}$} \\
\hline \multicolumn{7}{|l|}{ Sex } \\
\hline Male & $\begin{array}{c}14 \\
(35)\end{array}$ & $30 \pm 14$ & $45 \pm 14$ & $\begin{array}{c}18 \\
(45)\end{array}$ & $28 \pm 10$ & $84 \pm 9$ \\
\hline Female & $\begin{array}{c}26 \\
(65)\end{array}$ & $24 \pm 19$ & $37 \pm 18$ & $\begin{array}{c}22 \\
(55)\end{array}$ & $25 \pm 14$ & $83 \pm 7$ \\
\hline
\end{tabular}

$\mathrm{n}=$ number of subjects; $\mathrm{M}=$ mean; $\mathrm{SD}=$ st andard deviation 
Table 4. Effect of both types of Intervention on total knowledge score according to background characteristics (Academic Information) of study subjects

\begin{tabular}{|c|c|c|c|c|c|c|}
\hline \multirow{3}{*}{ Parameters } & \multicolumn{3}{|c|}{ TTM Group $(\mathrm{n}=40)$} & \multicolumn{3}{|c|}{ CFPTM Group $(\mathrm{n}=40)$} \\
\hline & \multirow{2}{*}{$\begin{array}{c}\mathrm{n} \\
(\%)\end{array}$} & Pre-intervention & Post-intervention & \multirow{2}{*}{$\begin{array}{c}\mathrm{n} \\
(\%)\end{array}$} & Pre-intervention & Post-intervention \\
\hline & & \multicolumn{2}{|c|}{$\mathrm{M} \pm \mathrm{SD}$} & & \multicolumn{2}{|c|}{$\mathrm{M} \pm \mathrm{SD}$} \\
\hline \multicolumn{7}{|c|}{ i. Le vel of Edu cation (last degree) } \\
\hline $\begin{array}{l}\text { Undergraduate/ } \\
\text { Bachelor }\end{array}$ & $\begin{array}{c}22 \\
(55)\end{array}$ & $23 \pm 19$ & $37 \pm 18$ & $\begin{array}{c}36 \\
(90) \\
\end{array}$ & $26 \pm 13$ & $83 \pm 7$ \\
\hline Postgraduate/ Masters & $\begin{array}{c}18 \\
(45) \\
\end{array}$ & $30 \pm 15$ & $43 \pm 15$ & $\begin{array}{c}4 \\
(10) \\
\end{array}$ & $30 \pm 8$ & $90 \pm 8$ \\
\hline \multicolumn{7}{|c|}{ ii. Basic background of education } \\
\hline Science & $\begin{array}{c}40 \\
(100 \\
\end{array}$ & $26 \pm 18$ & $40 \pm 17$ & $\begin{array}{c}38 \\
(95) \\
\end{array}$ & $26 \pm 13$ & $84 \pm 8$ \\
\hline Arts & 0 & 0 & 0 & $\begin{array}{c}2 \\
(5) \\
\end{array}$ & $35 \pm 7$ & $80 \pm 0$ \\
\hline \multicolumn{7}{|c|}{ iii. Medical background of students } \\
\hline Medical graduate & $\begin{array}{c}18 \\
(45) \\
\end{array}$ & $25 \pm 17$ & $39 \pm 18$ & $\begin{array}{c}15 \\
(38) \\
\end{array}$ & $30 \pm 11$ & $85 \pm 8$ \\
\hline Non medical graduate & $\begin{array}{c}22 \\
(55) \\
\end{array}$ & $27 \pm 18$ & $41 \pm 16$ & $\begin{array}{c}25 \\
(62) \\
\end{array}$ & $25 \pm 13$ & $83 \pm 8$ \\
\hline \multicolumn{7}{|c|}{ iv. Acade mic result of last degree } \\
\hline 1 st class & $\begin{array}{c}25 \\
(62) \\
\end{array}$ & $24 \pm 16$ & $39 \pm 17$ & $\begin{array}{c}21 \\
(52) \\
\end{array}$ & $28 \pm 12$ & $85 \pm 8$ \\
\hline 2nd class \& below & $\begin{array}{c}15 \\
(36)\end{array}$ & $29 \pm 20$ & $43 \pm 17$ & $\begin{array}{c}19 \\
(48)\end{array}$ & $25 \pm 13$ & $82 \pm 8$ \\
\hline
\end{tabular}

$\mathrm{n}=$ number of subjects; $\mathrm{M}=$ mean; $\mathrm{SD}=$ st andard deviation

Table 5. Effect of both types of Intervention on total knowledge score according to background characteristics (Professional Information) of study subjects

\begin{tabular}{|c|c|c|c|c|c|c|}
\hline \multirow{3}{*}{ Parameters } & \multicolumn{3}{|c|}{ TTM Group $(\mathrm{n}=40)$} & \multicolumn{3}{|c|}{ CFPTM Group $(\mathrm{n}=40)$} \\
\hline & \multirow{2}{*}{$\begin{array}{c}\mathrm{n} \\
(\%)\end{array}$} & Pre-intervention & Post-intervention & \multirow{2}{*}{$\begin{array}{c}\mathrm{n} \\
(\%)\end{array}$} & Pre-intervention & Post-intervention \\
\hline & & \multicolumn{2}{|c|}{$\mathrm{M} \pm \mathrm{SD}$} & & \multicolumn{2}{|c|}{$\mathrm{M} \pm \mathrm{SD}$} \\
\hline \multicolumn{7}{|c|}{ i. Types of present organization } \\
\hline Government & $\begin{array}{c}9 \\
(23) \\
\end{array}$ & $23 \pm 13$ & $33 \pm 20$ & $\begin{array}{c}15 \\
(38) \\
\end{array}$ & $26 \pm 14$ & $83 \pm 7$ \\
\hline $\begin{array}{l}\text { Non-Government/ } \\
\text { Private/Others }\end{array}$ & $\begin{array}{c}31 \\
(77) \\
\end{array}$ & $27 \pm 16$ & $42 \pm 16$ & $\begin{array}{c}22 \\
(62) \\
\end{array}$ & $29 \pm 10$ & $85 \pm 8$ \\
\hline \multicolumn{7}{|c|}{ ii. Attendance in different types of training } \\
\hline Yes & $\begin{array}{c}23 \\
(57) \\
\end{array}$ & $23 \pm 19$ & $37 \pm 18$ & $\begin{array}{c}24 \\
(60) \\
\end{array}$ & $26 \pm 14$ & $83 \pm 8$ \\
\hline No & $\begin{array}{c}17 \\
(43) \\
\end{array}$ & $30 \pm 15$ & $44 \pm 15$ & $\begin{array}{c}16 \\
(40) \\
\end{array}$ & $28 \pm 10$ & $86 \pm 7$ \\
\hline \multicolumn{7}{|c|}{ iii. Attendance in conference } \\
\hline Yes & $\begin{array}{c}21 \\
(52) \\
\end{array}$ & $28 \pm 16$ & $41 \pm 17$ & $\begin{array}{c}12 \\
(30) \\
\end{array}$ & $30 \pm 13$ & $84 \pm 9$ \\
\hline No & $\begin{array}{c}19 \\
(48) \\
\end{array}$ & $24 \pm 19$ & $39 \pm 17$ & $\begin{array}{c}28 \\
(70) \\
\end{array}$ & $25 \pm 12$ & $83 \pm 7$ \\
\hline \multicolumn{7}{|c|}{ iv. Published articles } \\
\hline Yes & $\begin{array}{c}6 \\
(15) \\
\end{array}$ & $35 \pm 13$ & $48 \pm 16$ & $\begin{array}{c}2 \\
(5) \\
\end{array}$ & $35 \pm 7$ & $95 \pm 7$ \\
\hline No & $\begin{array}{c}34 \\
(85)\end{array}$ & $25 \pm 18$ & $38 \pm 17$ & $\begin{array}{c}38 \\
(95)\end{array}$ & $26 \pm 13$ & $83 \pm 7$ \\
\hline
\end{tabular}

$\mathrm{n}=$ number of subjects; $\mathrm{M}=$ mean; $\mathrm{SD}=$ st andard deviation 


\section{Discussion}

In primary stage, both groups (CFPTM and TTM) have similar age and apply the educational intervention in both groups. Then the mean $( \pm \mathrm{SD})$ knowledge score were found forboth groups $43( \pm 17)$ and $83( \pm 8)$ respectively which was shown significant increase as pre-assessment knowledge score were $27( \pm 18)$ and $27( \pm 12)$ for TTM and CFPTM groups. Here, the CFPTM group's knowledge score was higher than TTM groups. This competency found in University at Albany which achieving Competence in Social Work through Field Education [2]. Another study recommended an enhancement of Health education theory, research, and training might lead to better foster succes sful efforts to modify social and political environments to improve health [3].

So it is clearly shown that there is significant variation exist between two groups as initial stage both groups knowledge score was quiet similar but after applying educational intervention CFPTM group's knowledge score was more than TTM group. Here the knowledge was examined based on the topic 'Planning, Implementation, and Evaluation of Health Educational Intervention'. Then this study examined a significant increase in section (i.e. planning component) where the pre-assessment knowledge score of this section were $31( \pm 24)$ and $36( \pm 22)$. However, after applying educational intervention, the score of planning component of CFP group was $93( \pm 10)$ which was higher than the knowledge score of TTM group though the significant $(p<0.001)$ increase of knowledge score was happened for both groups by applying educational intervention. Similarly, another study showed the benefits of modern teaching strategies using technological intervention in premises. Using modern teaching methods, the learning process becomes more effective and students become able to enrich their knowledge, imp rove their skills and competencies, which make them competitive in the practical field as well as pros pective successor in career [7].

For more checking, this study also examined the knowledge of implementation component for both CFPTM and TTM groups. Between the last scores of both groups, CFPTM group showed a significantly $(p<0.001)$ higher knowledge score as compared to TTM group in post-ass essment. A similar result was found in a systematic review approach, which was aimed to reveal the effectiveness of non-traditional educational methods in critical thinking skill. The meta-analysis showed that nontraditional teaching methods (i.e., no lectures) were more effective compared to control groups (standardized mean difference [SMD]: $0.42,95 \%$ confidence interval [CI]: $0.26-0.57, \mathrm{p}<.00001)$ [17].

In evaluation component of the topic, knowledge score of CFPTM group was more than TTM group in pre-assessment. Both groups showed a significant increase in knowledge score after using educational intervention. Then between the end scores of both groups, CFPTM group showed a significantly $(\mathrm{p}<0.001)$ higher knowledge score as compared to TTM group in post-assessment. Similarly, another study suggested that Educational meetings alone or combined with other interventions, can improve professional practice and healthcare outcomes for the patients [18].

This study explored that the three sections (planning, implementation \& evaluation) of the topic the knowledge score of CFPTM groups was significantly higher than TTM group after applying educational intervention.

\section{Conclusions}

CFP has been identified as an effective tool for postgraduate education in public health, which offers a new approach to equipping students with appropriate knowledge, and skills that they need not only in their learning period but also in their service life. Although, the extent of the success of CFP based post graduate education sometimes depends on the academic and professional background of students. Moreover, the effectiveness and scrutinize factors of CFP through longer-term educational intervention need to observe critically. Larger studies with other areas of public health need to be taken for better evaluation of CFP.

\section{REFERENCES}

[1] Shardlow SM. Educating professionals: Practice learning in health and social care. Routledge; 2016 Apr 29.

[2] Bogo M. Achieving competence in social work through field education. University of Toronto Press; 2010.

[3] Gebbie KM, Rosenstock L, Hernandez LM. Who will keep the public healthy? Educating public health professionals for the 21 st century.

[4] Miner KR, Richter DL. Curricular innovation and the science of public health education: a call to action.

[5] Gallego MA. Is experience the best teacher? The potential of coupling classroom and community-based field experiences. Journal of teacher education. 2001 Sep; 52(4):312-25.

[6] Flores IM. Developing Preservice Teachers' Self-Efficacy through Field-Based Science Teaching Practice with Elementary Students. Research in Higher Education Journal. 2015 Jan;27.

[7] Dimitrios B, Labros S, Nikolaos K, Koutiva M, Athanasios K. Traditional teaching methods vs. teaching through the application of information and communication technologies in the accounting field: Quo Vadis?. European Scientific Journal. 2013 Oct 1;9(28).

[8] Erwin PC, Brownson RC. The public health practitioner of the future. American journal of public health. 2017 Aug;107(8):1227-32.

[9] Kidd E. Promoting a sustainable workforce for health in 
Europe. Eurohealth. 2009; 15(1):20.

[10] Byrne D. Enabling Good Health for All: A reflection process for a new EU Health Strategy. European Commissioner for Health and Consumer Protection. 2004 Jul 15;15

[11] The University of California, Berkeley, School of Social Welfare Fieldwork Program. Fieldwork Program Manual (510) 642-1306 [Internet]. 2010 Nov 20 [cited 2019 Dec 15]. Available from: http://web.csulb.edu/colleges/chhs/depart ments/social-work/documents/2010-11MANUAL-BASW Fieldwork-numberrev10-20-10.pdf

[12] James R, McInnis C, Devlin M. Assessing learning in Australian universities: Ideas, strategies and resources for quality in student assessment. Australian, Universities Teaching Committee; 2002 Jan 1.

[13] Naslund JA, Aschbrenner KA, Marsch LA, Bartels SJ. The future of mental health care: peer-to-peer support and social media. Epidemiology and psychiatric sciences. 2016 Apr;25(2):113-22.

[14] The university of Wollongong. Code of Practice - Teaching \& Assessment [Internet]. 2002 [cited 2019 Dec 12]. Available from: https://documents.uow.edu.au/content/gro ups/public/@web/@gov/documents/doc/uow008723.pdf

[15] Richey RC, Klein JD, Tracey MW. The instructional design knowledge base: Theory, research, and practice. Routledge; 2010 Oct 18.

[16] Suryavanshi S, Tawalare K. Comparative study of case based learning to traditional teaching method in the students of third BAMS. Journal of Education Technology in Health Sciences. 2014.

[17] Lee J, Lee Y, Gong S, Bae J, Choi M. A meta-analy sis of the effects of non-traditional teaching methods on the critical thinking abilities of nursing students. BMC medical education. 2016 Dec; 16(1):240.

[18] Forsetlund L, Bjørndal A, Rashidian A, Jamtvedt G, O'Brien MA, Wolf FM, Davis D, Odgaard - Jensen J, Oxman AD. Continuing education meetings and workshops: effects on professional practice and health care outcomes. Cochrane database of sy stematic reviews. 2009(2). 